\title{
Physico-Chemical Properties of Soil and Mineral Composition of Plants as Affected by Fox Nut-Based Cropping Systems
}

\author{
I.S. Singh*, Manoj Kumar, A.K. Thakur ${ }^{1}$, A.K. Choudhary ${ }^{2}$, B.P. Bhatt ${ }^{2}$, S.P. Singh ${ }^{3}$ \\ and S. S. Prasad ${ }^{3}$ \\ ICAR Research Complex for Eastern Region, Research Centre for Makhana, Darbhanga-846005, Bihar, India \\ ${ }^{I}$ ICAR-National Institute of Natural Fibre Engineering and Technology, Kolkata- 700040, West Bengal, India \\ ${ }^{2}$ ICAR Research Complex for Eastern Region, Patna-800014, Bihar, India \\ ${ }^{3}$ Department of Soil Science, Rajendra Agricultural University, Pusa-848125, Bihar, India
}

\begin{abstract}
Foxnut (Euryale ferox Salisb.) is exclusively an aquatic crop and generally grown naturally in non-saline wetland areas having stagnant water. Prolonged submergence in lowlands impedes the cultivation of most field crops except few one such as rice. For enhancing the system productivity, crop diversification technology needs to be adopted in wetland/aquatic ecosystems as well. In present study fox nutbased eight different crop rotations, viz. fox nut-fox nut, fox nut-rice, fox nut-wheat, fox nut-berseem, fox nut-water chestnut, fox nut-rice-wheat, fox nut-rice-berseem and fox nut-water chestnut-berseem were followed consecutively for three years (2012-13 to 2015-16). The pooled data showed that fox nut-water chestnut-berseem cropping system had more organic carbon, available N, P and $\mathrm{K}$ to the tune of $25 \%$, $14.75 \%, 26.66 \%$ and $6.80 \%$, respectively over the fox nut-fox nut cropping system. The soils under fox nut-rice-berseem cropping system had the highest concentration of DTPA Cu $\left(1.82 \mathrm{mg} \mathrm{kg}^{-1}\right)$ and $\mathrm{Zn}\left(0.35 \mathrm{mg} \mathrm{kg}^{-1}\right)$. Fox nut and water chestnut retained the highest tissue concentrations of the less soluble Fe and $\mathrm{Mn}$ and $\mathrm{P}, \mathrm{Cu}$ and $\mathrm{Zn}$. The results indicated that adoption of fox nut-water chestnut-berseem cropping system significantly improvedthe fertility status of soil in the aquatic low land ecosystem.
\end{abstract}

Key words: Cropping systems, fox nut, water chestnut, rice, berseem, plant nutrients, soil fertility

\section{Introduction}

Fox nut or Gorgon nut (Euryale ferox Salisb.), popularly known as makhana in India, is an important annual aquatic herb of Nymphaeaceae family. It has been widely distributed in the aquatic/wetland ecosystem of eastern India, China, Korea, Eastern Russia and Japan. In the lowland ecosystem of eastern India (parts of eastern Uttar Pradesh, Bihar, West Bengal, Assam, Chhattisgarh and Manipur), it is cultivated as a cash crop for its seeds. Bihar not only

*Corresponding author: (Email: induciah@rediffmail.com) contributes $80 \%$ of India's total production $(23,000$ tonnes) of makhana seeds (Jha et al. 2012) but it also covers $85 \%$ of total land areas under makhana cultivation (15,294 hectares). It has attained the status of an industrial crop due to commercialization of popped form (white puffs) of its seeds. The starchy white puffs are marketed as a premium dry fruit similar to cashew nut or almond. Besides this, fox nut seeds have various medicinal properties, leading to its use in Ayurvedic and Chinese medicines (Kumar et al.2015).

Traditionally considered a crop of deep-water ponds, swamps and ditches (1.20-1.80 m depth) worldwide, fox nut in India is grown in both deep-water 
pond and lowland agricultural fields with $0.15-0.60 \mathrm{~m}$ water depth. It is a crop of the tropical and sub-tropical climate and for its proper growth and development, the conducive range of air temperature, relative humidity and annual rainfall is $20-35^{\circ} \mathrm{C}, 50-90 \%$ and $1000-2500$ $\mathrm{mm}$, respectively (Mandal et al. 2010). As an aquatic crop, it requires assured availability of water to be standing permanent throughout its growth period.

Besides fox nut, traditional ponds in eastern India are also used for growing another aquatic crop, called water chestnut (Trapa bispinosa), however, farmers grow annually only one of these two. Water chestnut is an annual floating emergent macrophyte and found worldwide in wetland ecosystems. In India, it is popularly known as singhara or paani phal, and is mainly grown in Madhya Pradesh, Uttar Pradesh, Bihar and Odisha. It requires standing water depth of 0.5-1.5 m throughout its growth period (August to November). Plants have a well-developed adventitious root system which enhances the absorption capacity of the nutrients directly from the soil solution through root surfaces. The timing of cultivation makes it worth-fitting in crop rotation with other aquatic crop like fox nut, especially when it is cultivated under field condition (lowland). Five major makhana based cropping systems, i.e., makhana-water chestnut, makhana-berseem, makhanarice, makhana-wheat and makhana-rice-wheat were found economically beneficial and sustainable in terms of maintenance of soil health and to increase the system productivity (Kumar et al. 2011).

Under crop cultivation, changes in SOM status would determine the dynamics of alluvial soil quality in wetlands (Jha and Dutta 2003). In addition to fox nut, other components of crops may also likely to add organic matter to the soil. Kumar et al. (2013) reported that fox nut and water chestnut add substantial amounts of organic matter (6-10 tha ${ }^{-1}$ and 2-3 $\mathrm{tha}^{-1}$ respectively) to the soil. Besides this, the organic matter contributed by the preceding crop, in a particular crop rotation, can incorporate $\mathrm{N}$ leading to the increased and sustained productivity of all kinds of crops. Carter et al. (2002) reported that crop rotation could have a significant impact on soil health due to soil ecological interactions and processes that occur with time. These include improvement of soil structural stability, nutrient use efficiency and SOM levels. Crop rotations can also increase $\mathrm{N}$ availability when $\mathrm{N}$-fixing legumes are included in the system (Galantini et al. 2000). Legumes, cultivated as one of the cropping systems, can assist in soil improvement, particularly when used as green manure crops. Fixed $\mathrm{N}$ and in some cases, $\mathrm{P}$ are made available for the succeeding crops and the added organic matter contributes to the improvement of soil structure. Varvel (2000) also reported that judicious crop rotation systems are more effective in reducing the long-term yield variability than monoculture systems, and can increase total soil $\mathrm{C}$ and $\mathrm{N}$ concentrations over time that may further improve soil productivity.

The nutrient absorption capacity of aquatic and non-aquatic crops differs a lot due to differential cell growth, tissue water content, nutrient requirement and soil condition. Aquatic macrophytes, as they grow in standing water, are able to acquire nutrients from the sediment as well as the water column (Rattray et al. 1991). The degree to which they use these two resources is probably related to their relative available proportions. Some aquatic macrophytes are known to be efficient removers of nutrients. The tissue nutrient concentrations of many macrophytes are reported to be dependent on the concentrations of $\mathrm{N}$ and $\mathrm{K}$ in the surrounding water (Portielje and Roijackers 1995). This suggests "luxury" uptake of nutrients (particularly of $\mathrm{N}$ and $\mathrm{K}$ ).

In general, the response of lowland fox nut to the quantum of organic matter available in the soil system is usually higher than that of other lowland crops like rice and water chestnut, primarily because of the higher requirement of $\mathrm{N}, \mathrm{P}, \mathrm{K}, \mathrm{Fe}, \mathrm{Mn}$ and $\mathrm{Zn}$, and easy availability of these nutrients in the soil solution under water-logged condition. The information on the cyclical pattern of nutrients under fox nut-based cropping systems is lacking. This paper reports the effect of different fox nut-based cropping systems on the fertility status of the silty clay loam soil of the Eastern IndoGangetic Plains.

\section{Materials and Methods}

The field trial (2012 to 2015) was located at $26^{\circ}$ $10^{\prime} \mathrm{N}$ and $85^{\circ} 87^{\prime} \mathrm{E}$ at an altitude of $49 \mathrm{~m}$ above mean sea 
level with a mean annual rainfall of 1150 (AdwaraKamla flood plain) of Eastern India. The experiment was conducted at the experimental farm of the Research Centre for Makhana, Darbhanga. Prior to the experiment, the field had not been under any cropping. Fox nut, rice (Oryza sativa), wheat (Triticum aestivum), berseem (Trifolium alexandrium) and water chestnut (Trapa bispinosa) were the test crops. The soils of the experimental site are silty clay loam of Inceptisol order with crumb structure. The soil-site properties, prior to the experiment, are presented in table 1.

Table 1. Initial soil-site properties of the experiment farm

\begin{tabular}{|c|c|c|c|}
\hline Soil-site property & Value & Soil-site property & Value \\
\hline Bulk density $\left(\mathrm{Mg} \mathrm{m}^{-3}\right)$ & 1.47 & Mg hardness (mg $\left.1^{-1}\right)$ & 5.35 \\
\hline Particle density $\left(\mathrm{Mg} \mathrm{m}^{-3}\right)$ & 2.51 & dissolved oxygen $\left(\mathrm{mg} \mathrm{l}^{-1}\right)$ & 6.0 \\
\hline Porosity $(\%)$ & 41.43 & Total N (\%) & 0.025 \\
\hline Soil moisture retention capacity (\%) & & Total P (\%) & 0.012 \\
\hline $33 \mathrm{k} \mathrm{Pa}$ & 38 & & \\
\hline $1500 \mathrm{k} \mathrm{Pa}$ & 20 & Total K (\%) & 0.201 \\
\hline pH & 7.01 & Inorganic $\mathrm{N}\left(\right.$ ug $^{-1}$ ) & 400 \\
\hline Electrical conductivity $\left(\mathrm{dS} \mathrm{m}^{-1}\right)$ & 0.10 & Inorganic $\mathrm{P}\left(\mathrm{mg} \mathrm{l}^{-1}\right)$ & 5.55 \\
\hline Organic carbon $(\%)$ & 0.40 & $\mathrm{Ca}\left(\mathrm{mg} \mathrm{l}^{-1}\right)$ & 2.12 \\
\hline $\operatorname{CEC}\left(\mathrm{cmol}\left(\mathrm{p}^{+}\right) \mathrm{kg}^{-1}\right)$ & 20 & $\operatorname{Mg}\left(\mathrm{mg} \mathrm{l}^{-1}\right)$ & 0.70 \\
\hline $\mathrm{pH}$ of irrigation water & 6.6 & Chloride $\left(\mathrm{Cl}^{-1}\right)\left(\mathrm{mg} \mathrm{kg}^{-1}\right)$ & 7.20 \\
\hline $\begin{array}{l}\text { Electrical conductivity of irrigation water } \\
\left(\mathrm{dS} \mathrm{m}^{-1}\right)\end{array}$ & 0.00331 & $\mathrm{Fe}\left(\mathrm{mg} \mathrm{l}^{-1}\right)$ & 55 \\
\hline Alkalinity $\left(\mathrm{mg}^{-1}\right)$ & 80 & $\operatorname{Mn}\left(\mathrm{mg} \mathrm{l}^{-1}\right)$ & 80 \\
\hline Total acidity $\left(\mathrm{mg}^{-1}\right)$ & 10 & $\mathrm{Cu}\left(\mathrm{mg} \mathrm{l}^{-1}\right)$ & 22 \\
\hline Total hardness ( $\left.\mathrm{mg} \mathrm{l}^{-1}\right)$ & 12.80 & $\mathrm{Zn}\left(\mathrm{mg} \mathrm{l}^{-1}\right)$ & 40 \\
\hline Ca hardness ( $\left.\mathrm{mg} \mathrm{l}^{-1}\right)$ & 7.45 & & \\
\hline
\end{tabular}

The three cropping seasons include a rainy or kharif season from July to October, a winter or rabi season from November to February, and summer or dry season from March to May. Rainfall during the rainy season always exceeds evaporation, while in winter and dry seasons, the reverse was the case. The experiment was laid out in a randomized block design with $30 \mathrm{~m} \mathrm{X}$ $20 \mathrm{~m}$ plots replicated thrice. Eight cropping systems consisting of Fox nut-Fox nut, Fox nut-rice, Fox nutwheat, Fox nut-berseem, Fox nut-water chestnut, Fox nut-rice-wheat, Fox nut-rice-berseem and Fox nut-water chestnut-berseem were compared with the mono cropping of Fox nut-Fox nut. Each cropping system was repeated thrice, resulting in two to three crops grown within three years. Land for all crops was prepared with a tractor-drawn mould board plough. Rice seedlings were
20 days old for wet season rice. For all other crops, seeds were directly sown by hand. All crops in the various cropping systems received recommended doses of fertilizer (Table 2). Need-based irrigation was given to each crop with groundwater. Yields of main and byproducts of each crop under various cropping systems were measured by hand-harvest of a $20 \mathrm{~m}^{2}$ area in each plot at physiological maturity. All crops were cut at about $15 \mathrm{~cm}$ from the surface, except fox nut and water chestnut. The economic part of individual crops was separated manually after harvesting. Yields were measured for both fresh and dry weights. Sub-samples of the main product and byproduct were oven-dried to constant weight at $70^{\circ} \mathrm{C}$ for $72 \mathrm{~h}$ and ground in a Wiley mill to pass through a $1 \mathrm{~mm}$ sieve. 
Initial soil samples were collected with an auger for the $0-15 \mathrm{~cm}$ soil depth at 10 locations of the experimental area. After harvesting the crop, soil samples were also collected and analyzed for each crop of the cropping systems under different treatments. The samples were thoroughly mixed and passed through a 2 $\mathrm{mm}$ sieve and kept in poly bags for analysis of available $\mathrm{N}, \mathrm{P}, \mathrm{K}, \mathrm{Fe}, \mathrm{Mn}, \mathrm{Cu}$ and $\mathrm{Zn}$ following standard methods as described by Jackson (1973). Plant samples were taken at physiological maturity for fox nut, rice, wheat, berseem and water chestnut during each cropping season for the determination of N, P, K, Fe, Mn, Cu and $\mathrm{Zn}$ in economic and byproduct parts of the plant. Nutrient contents in plant parts were measured using standard procedures (Jackson 1973). Soils with DTPA extractable $\mathrm{Fe}, \mathrm{Mn}, \mathrm{Cu}$ and $\mathrm{Zn}$ less than 4.5, 2.0, 0.2 and $0.6 \mathrm{mg} \mathrm{kg}^{-1}$, respectively were considered deficient (Lindsay and Norvell 1978). Critical limits of 50, 20, 4 and $20 \mathrm{mg} \mathrm{kg}^{-1}$ were taken for $\mathrm{Fe}, \mathrm{Mn}, \mathrm{Cu}$ and $\mathrm{Zn}$, respectively in deficient plant samples. All nutrient concentrations in plant samples were expressed on a dry weight basis. Mean nutrient concentrations in the plant material of each crop were calculated.

The data, recorded under laboratory and field conditions, was statistically analyzed using OPSTAT online Agriculture Data Analysis developed by the CCS Haryana Agricultural University, Hisar, Haryana, India. The details of crop cultivars and their agronomic practices adopted in the study are given in table 2 .

Table 2. Details of crop cultivars and their agronomic practices

\begin{tabular}{|c|c|c|c|c|c|c|}
\hline \multirow[t]{2}{*}{ Crops } & \multirow[t]{2}{*}{ Cultivar } & \multirow{2}{*}{$\begin{array}{c}\text { Duration } \\
\text { (Days) }\end{array}$} & \multirow{2}{*}{$\begin{array}{c}\text { Inter and } \\
\text { intra row } \\
\text { spacing (cm) }\end{array}$} & \multicolumn{3}{|c|}{ Recommended dose of nutrients } \\
\hline & & & & $\begin{array}{c}\mathrm{N} \\
\left(\mathrm{kg} \mathrm{ha}^{-1}\right)\end{array}$ & $\begin{array}{c}\mathrm{P} \\
\left(\mathrm{kg} \mathrm{ha}^{-1}\right)\end{array}$ & $\begin{array}{c}\mathrm{K} \\
\left(\mathrm{kg} \mathrm{ha}^{-1}\right)\end{array}$ \\
\hline Fox nut & Selection-6 & 150 & $125 \times 125$ & 100 & 60 & 40 \\
\hline Rice & $\begin{array}{c}\text { Improved } \\
\text { variety }\end{array}$ & 140 & $15 \times 20$ & 80 & 40 & 40 \\
\hline Wheat & $\begin{array}{l}\text { Improved } \\
\text { variety }\end{array}$ & 115 & $15 \times 20$ & 60 & 40 & 30 \\
\hline Berseem & $\begin{array}{l}\text { Improved } \\
\text { variety }\end{array}$ & 70 & - & 20 & 80 & - \\
\hline $\begin{array}{l}\text { Water } \\
\text { chestnut }\end{array}$ & Local & 70 & $100 \times 100$ & 40 & 60 & 40 \\
\hline
\end{tabular}

\section{Results and Discussion}

Physical properties of soil under different Fox nut-based cropping system

There was an improvement in bulk density of soil with Fox nut-fox nut $\left(1.28 \mathrm{Mg} \mathrm{m}^{-3}\right)$, Fox nut-water chestnut $\left(1.30 \mathrm{Mg} \mathrm{m}^{-3}\right)$ and Fox nut-water chestnutberseem $\left(1.25 \mathrm{Mg} \mathrm{m}^{-3}\right)$ cropping systems over its initial value (Table 3 ). No change in particle density could be recorded during the period of the experiment. The significant improvement in the porosity percentage over its initial value was noticed under all the cropping system except Fox nut-rice. The improvement in bulk density under these cropping systems may be attributed to the higher addition of organic matter and more soil faunal activity in the upper region of the soil (Balamurugan et al. 2000). Fox nut-water chestnutberseem cropping had the highest water holding capacity of soil at $33 \mathrm{k} \mathrm{Pa} \mathrm{(46 \% )} \mathrm{and} 1500 \mathrm{k} \mathrm{Pa}(25 \%)$ followed by Fox nut-water. Similar findings were also reported by Aggrawal et al.(1997). 
Table 3. Mean values of physical properties of soil under different cropping

\begin{tabular}{lccccc}
\hline \multicolumn{1}{c}{ Cropping systems } & $\begin{array}{c}\text { BD } \\
\left(\mathbf{M g ~ m}^{-\mathbf{3}}\right)\end{array}$ & $\begin{array}{c}\text { PD } \\
\left(\mathbf{M g ~ m}^{-\mathbf{3}}\right)\end{array}$ & Porosity (\%) & $\begin{array}{c}\text { WHC at F.C. } \\
\mathbf{( \% )}\end{array}$ & $\begin{array}{c}\text { WHC at W.P. } \\
\mathbf{( \% )}\end{array}$ \\
\hline Fox nut-Fox nut & 1.28 & 2.50 & 48.80 & 40 & 21 \\
Fox nut-wheat & 1.42 & 2.50 & 43.20 & 38 & 19 \\
Fox nut-rice & 1.46 & 2.51 & 41.83 & 37 & 19 \\
Fox nut-berseem & 1.40 & 2.50 & 44.00 & 38 & 17 \\
Fox nut-water chestnut & 1.30 & 2.51 & 48.20 & 42 & 21 \\
Fox nut-rice-wheat & 1.45 & 2.50 & 42.00 & 39 & 18 \\
Fox nut-rice-berseem & 1.37 & 2.50 & 45.20 & 38 & 18 \\
Fox nut-water chestnut- & 1.25 & 2.50 & 50.00 & 46 & 25 \\
berseem & & & & \\
C.D. $(P=0.05)$ & $\mathrm{NS}$ & $\mathrm{NS}$ & 0.957 & 3.114 & 1.330 \\
\hline
\end{tabular}

There is no significant change in $\mathrm{pH}$ and $\mathrm{EC}$ of the soils under eight cropping systems (Table 4). Increased availability of nutrients was observed in Fox nut-water chestnut-berseem cropping system. Fox nutwater chestnut-berseem had the highest content of organic carbon $(0.80 \%)$ which is $8.75-25 \%$ higher than other cropping systems. Due to the inclusion of berseem, this cropping system also added more the above-ground biomass of crop residues. Intensive Fox nut-water chestnut-berseem and Fox nut-berseem cropping system utilize the fallow period after harvesting of Fox nut and water chestnut and in-turn, improve the SOC content. Increase in SOC in cropping systems with pulses as compared with the rice-wheat systems could be attributed to the addition of more below ground biomass in the form of the root (Ganeshamurthy 2009).

Fox nut-water chestnut-berseem had $305 \mathrm{~kg} \mathrm{~N}$ $\mathrm{ha}^{-1}$ followed by Fox nut-berseem $\left(281 \mathrm{~kg} \mathrm{ha}^{-1}\right)$, Fox nutwheat $\left(269 \mathrm{~kg} \mathrm{ha}^{-1}\right)$ and Fox nut-water chestnut $(268 \mathrm{~kg}$ $\mathrm{ha}^{-1}$ ), while the minimum $\mathrm{N}$ was found with Fox nutrice-wheat (Table 4). Singh et al. (2014) reported an improved available $\mathrm{N}$ content in soil due to sole cropping of Fox nut and Fox nut-berseem cropping system. The highest values of available N, P and K were noticed under Fox nut-water chestnut-berseem cropping system owing to the inclusion of berseem, a N-fixer. The early decomposition of the green succulent berseem might have caused early release and availability of nutrients in the soil solution (Bellaki and Badanaur 1994) and also favouring the mineralization of organic matter.

In all the cropping systems, the available $\mathrm{P}$ was found to be medium ranging between $15 \mathrm{~kg} \mathrm{ha}^{-1}$ (Fox nutrice) and $30 \mathrm{~kg} \mathrm{ha}^{-1}$ (Fox nut-water chestnut-berseem) (Table 4). In the Fox nut-water chestnut-berseem cropping system, the higher available soil $\mathrm{P}$ might be due to production of organic acids during microbial decomposition of the crop residues (Jha and Rattan 2007) and green manure in soil and decrease in soil pH. Further, dense beds of roots of fox nut and water chestnut may increase the release rate of dissolved phosphate from sediment due to the favourable $\mathrm{pH}$ caused by inorganic carbon dynamics (Barko and James 1998). The increase in available $\mathrm{P}$ might be attributed to the reduction of ferric phosphate to the more soluble ferrous form, and to the hydrolysis of $\mathrm{P}$ compounds. The higher accumulation of total $\mathrm{P}$ in soil might be from the decomposition of succulent biomass of berseem and crop residues of fox nut and water chestnut. The increased $\mathrm{pH}$, as a result of submergence, also enhances the solution concentration of $\mathrm{Fe}$ and $\mathrm{Al}$ phosphate (Patrick and Mikkelsen 1971).

The available K ranged between 210 (Fox nutrice-berseem) and $240 \mathrm{~kg} \mathrm{ha}^{-1}$ (Fox nut-water chestnut) under different cropping systems (Table 4). The higher concentration of $\mathrm{K}$ in the soils with Fox nut-water chestnut-berseem cropping may be attributed to 
flooding resulting in a larger fraction of the $\mathrm{K}^{+}$being displaced from the exchange complex into the soil solution. Further, the crop residues of Fox nut, water chestnut and berseem might have also added $\mathrm{K}$ to the available pool of the soil (Kumar and Prasad 2008) and through a reduction in fixation via interaction of organic matter with clay (Pannu et al. 2001) or displacement of some of the $\mathrm{K}$ ions by $\mathrm{NH}^{4+}, \mathrm{Fe}^{2+}$ and $\mathrm{Mn}^{2+}$ from the exchange complex to the soil solution.

Table 4. Mean values of chemical properties of soil under different cropping system

\begin{tabular}{|c|c|c|c|c|c|c|}
\hline Cropping systems & pH & 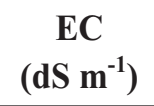 & $\begin{array}{c}\text { Org. C. } \\
(\%)\end{array}$ & $\begin{array}{c}\text { Av. N } \\
\left(\mathrm{kg} \mathrm{ha}^{-1}\right)\end{array}$ & $\begin{array}{c}\text { Av. P } \\
\left(\mathrm{kg} \mathrm{ha}^{-1}\right)\end{array}$ & $\begin{array}{c}\text { Av. K } \\
\left(\mathrm{kg} \mathrm{ha}^{-1}\right)\end{array}$ \\
\hline Fox nut-Fox nut & 7.25 & 0.15 & 0.60 & 260 & 22 & 219 \\
\hline Fox nut-wheat & 7.50 & 0.16 & 0.71 & 269 & 18 & 214 \\
\hline Fox nut-rice & 6.50 & 0.20 & 0.65 & 210 & 15 & 220 \\
\hline Fox nut-berseem & 6.73 & 0.20 & 0.70 & 281 & 23 & 215 \\
\hline Fox nut-water chestnut & 7.25 & 0.21 & 0.73 & 268 & 20 & 240 \\
\hline Fox nut-rice-wheat & 7.51 & 0.18 & 0.70 & 206 & 19 & 213 \\
\hline Fox nut-rice-berseem & 7.20 & 0.18 & 0.72 & 238 & 18 & 210 \\
\hline $\begin{array}{l}\text { Fox nut -water chestnut } \\
\text { berseem }\end{array}$ & 7.43 & 0.25 & 0.80 & 305 & 30 & 235 \\
\hline C.D. $(P=0.05)$ & 0.075 & 0.011 & N/A & 12.940 & 4.325 & 34.160 \\
\hline
\end{tabular}

Micronutrient content of soil under Fox nut-based cropping systems

The Fox nut-water chestnut-berseem cropping system had the highest Fe content ( $43 \mathrm{mg} \mathrm{kg}^{-1}$ ) followed by Fox nut-water chestnut ( $41 \mathrm{mg} \mathrm{kg}^{-1}$ ), Fox nut-Fox nut (38 $\left.\mathrm{mg} \mathrm{kg}^{-1}\right)$, Fox nut-rice (34 $\left.\mathrm{mg} \mathrm{kg}^{-1}\right)$, Fox nut-berseem (34 $\mathrm{mg} \mathrm{kg}^{-1}$ ), and Fox nut-rice-berseem (33 $\mathrm{mg} \mathrm{kg}^{-1}$ ) cropping systems (Table 5). As per critical limit of 4.5 $\mathrm{mg} \mathrm{kg}^{-1}$ soil (Lindsay and Norvell 1978), the soils were sufficient in available Fe. The Fox nut-water chestnutberseem cropping system had the highest Mn content, but the available Mn in this system was found to be at par with the Mn in the Fox nut-Fox nut (14.00 $\mathrm{mg} \mathrm{kg}^{-1}$ ), Fox nut-rice $\left(14.50 \mathrm{mgkg}^{-1}\right)$ and Fox nut-water chestnut (14.00 $\mathrm{mgkg}^{-1}$ ) systems (Table 5). The higher availability of $\mathrm{Fe}$ and $\mathrm{Mn}$ in the Fox nut-water chestnutberseem cropping system may be attributed to variation in the anaerobic condition of the soil system due to cultivation of crops like fox nut and water chestnut and accumulation of higher organic matter in the soil resulting in higher biological activity (Verma et al. 2005). The organic carbon, which influences the solubility and availability of Fe by chelation (with phytosiderophores) effect, might have protected the $\mathrm{Fe}$ from oxidation and precipitation and increased the availability of Fe during the decomposition of organic matter/crop residues (Sekhar et al. 2014).

The soils under Fox nut-rice-berseem cropping system contained the highest concentration of $\mathrm{Cu}(1.82$ $\left.\mathrm{mg} \mathrm{kg}^{-1}\right)$ and $\mathrm{Zn}\left(0.35 \mathrm{mg} \mathrm{kg}^{-1}\right)$ which are 8.79 and 14.28 $\%$ higher than Fox nut-water chestnut-berseem. The lower values of $\mathrm{Cu}$ and $\mathrm{Zn}$ in the soils of the Fox nutwater chestnut-berseem cropping system could be due to the reaction with soluble silica and their lower solubility caused by the formation of hydroxides, carbonates and sulphides. The flooding condition during the cultivation of fox nut and alternate wetting and drying conditions during rice cultivation and drying during the cultivation of berseem favours the availability of $\mathrm{Cu}$ and $\mathrm{Zn}$ concentration in soil with the Fox nut-rice-berseem cropping system. Zhang et al. (1989) stated that the presence of comparatively higher organic matter can promote the availability of $\mathrm{Zn}$, presumably by supplying soluble complexing agents. At high $\mathrm{pH}$, organic matters appear to increase the availability of $\mathrm{Zn}$. 
Table 5. Mean values of available micronutrient content of soil under different cropping system (Mean data)

\begin{tabular}{lcccc}
\hline \multicolumn{1}{c}{ Cropping systems } & $\begin{array}{c}\mathbf{F e} \\
(\mathbf{m g ~ k g}\end{array}$ & $\begin{array}{c}\mathbf{M n} \\
(\mathbf{m g ~ k g})\end{array}$ & $\begin{array}{c}\mathbf{C u} \\
\left(\mathbf{m g ~ k g}^{-\mathbf{1}}\right)\end{array}$ & $\begin{array}{c}\mathbf{Z n} \\
\left(\mathbf{m g ~ k g}^{-\mathbf{1}}\right)\end{array}$ \\
\hline Fox nut-Fox nut & 38 & 14.00 & 0.85 & 0.24 \\
Fox nut-wheat & 28 & 11.00 & 0.87 & 0.26 \\
Fox nut-rice & 34 & 14.50 & 0.80 & 0.23 \\
Fox nut-berseem & 34 & 11.30 & 1.65 & 0.26 \\
Fox nut- water chestnut & 41 & 14.00 & 1.16 & 0.28 \\
Fox nut-rice-wheat & 31 & 8.13 & 1.55 & 0.24 \\
Fox nut-rice-berseem & 33 & 9.27 & 1.82 & 0.35 \\
Fox nut-water chestnut-berseem & 43 & 15.15 & 1.66 & 0.30 \\
C.D. $(P=0.05)$ & 8.024 & 3.785 & 0.141 & 0.046 \\
\hline
\end{tabular}

\section{Chemical composition of plants}

Berseem plant had the highest $\mathrm{N}$ content $(2.96$ $\%$ ) while the lowest was in the fox nut $(0.27 \%)$ (Table 6). Considering $1 \%$ as the critical limit, fox nut, rice, wheat and water chestnut were deficient in N. Biomass N concentration in flooded plants such as fox nut and water chestnut decreased significantly as flood-induced microbial denitrification in the soil reduces the supply of nitrate to plants (Gambrell et al. 1991).

None of the aquatic plants had $\mathrm{P}$ content below $0.2 \%$, which is considered to be the critical limit for $\mathrm{P}$ content. Berseem had the adequate amount of tissue-P, but rice and wheat were deficient. Rattaray et al. (1991) reiterated that some aquatic macrophytes are known to be efficient removers of some nutrients.

Rice $(1.38 \%)$ and wheat $(1.18 \%)$ and berseem had a sufficient amount of tissue-K. Based on critical limit of $1.0 \%$, fox nut and water chestnut were deficient of tissue-K. Prolonged flooding of soil decreased the concentration of $\mathrm{K}$ in biomass of fox nut and water chestnut, owing to lower transport of $\mathrm{K}$ to shoots under flooding (Ponnamperuma 1972). Deficiency of root oxygen decreases the selectivity of $\mathrm{K}^{+}$uptake by roots due to accumulation of excessive concentration of $\mathrm{Fe}$ and $\mathrm{Mn}$ in root tissues.

$\mathrm{Fe}$ and $\mathrm{Mn}$ were highest in the fox nut while the highest concentration of $\mathrm{Cu}$ and $\mathrm{Zn}$ was recorded in water chestnut. Considering the critical limit of $\mathrm{Fe}(50$ $\left.\mathrm{mg} \mathrm{kg} \mathrm{g}^{-1}\right)$, the rice $\left(35 \mathrm{mg} \mathrm{kg}^{-1}\right)$ and wheat $\left(25 \mathrm{mg} \mathrm{kg}^{-1}\right)$ crops found to be deficient. The crops had Mn (20 to 924 $\mathrm{mg} \mathrm{kg}^{-1}$ ) in the tissue against the critical limit of $20 \mathrm{mg}$ $\mathrm{kg}^{-1}$. Uptake of Fe and $\mathrm{Mn}$ depends on plant species, and their availability in soils increases with flooding (Jones 1972). The higher concentrations of Fe and $\mathrm{Mn}$ in fox nut and water chestnut could be attributed to the excessive uptake of soluble $\mathrm{Fe}^{2+}$ and $\mathrm{Mn}^{2+}$ during prolonged inundation of the soil. Aquatic macrophytes differ both in their capacity to take up metals in root tissues and in the proportion of metals transferred to the above-ground parts (Lan et al. 1992).

Considering $4 \mathrm{mg} \mathrm{kg}^{-1}$ (Jones 1972) as the critical limit for $\mathrm{Cu}$, all the crops were found to have sufficient content of $\mathrm{Cu}$ in their tissues, although the soil samples were deficient in DTPA Cu content. None of the crops showed $\mathrm{Zn}$ below the critical of $20 \mathrm{mg} \mathrm{kg}^{-1}$ barring berseem. Compared to the average values of the $\mathrm{Zn}$ concentration in plants (Rattan et al. 2009), fox nut, rice and water chestnut are sufficient in $\mathrm{Zn}$ content, but the soils were deficient in DTPA Zn. Campbell et al. (1988) reiterated that metals that preferentially bind to organic ligands, like $\mathrm{Cu}$ and $\mathrm{Zn}$ should be less available to rooted aquatic macrophytes when such ligands are available for binding. Guilizzoni (1991) opined that some rooted submerged plants might absorb metals directly from water when they are not readily available in sediments and/or in high concentrations in the surroundings. The positive residual impact and its contribution towards the enrichment of soil fertility of all the crops grown in 
Table 6. Mean contents of inorganic elements in biomass of crops due to Fox nut based cropping systems

\begin{tabular}{lccccccc}
\hline \multicolumn{1}{c}{ Crops } & $\begin{array}{c}\mathbf{N} \\
\mathbf{( \% )}\end{array}$ & $\begin{array}{c}\mathbf{P} \\
\mathbf{( \% )}\end{array}$ & $\begin{array}{c}\mathbf{K} \\
\mathbf{( \% )}\end{array}$ & $\begin{array}{c}\mathbf{F e} \\
(\mathbf{m g ~ k g})\end{array}$ & $\begin{array}{c}\mathbf{M n} \\
\left(\mathbf{m g ~ k g}^{-\mathbf{1}}\right)\end{array}$ & $\begin{array}{c}\mathbf{C u} \\
\left(\mathbf{m g ~ k g}^{-\mathbf{1}}\right)\end{array}$ & $\begin{array}{c}\mathbf{Z n} \\
\left(\mathbf{m g ~ k g}^{-\mathbf{1}}\right)\end{array}$ \\
\hline Fox nut & 0.27 & 0.45 & 0.37 & 2175 & 924 & 6.3 & 93 \\
Rice & 0.42 & 0.18 & 1.38 & 35 & 30 & 7.4 & 25 \\
Wheat & 0.48 & 0.16 & 1.18 & 25 & 20 & 5.5 & 20 \\
Water chestnut & 0.40 & 0.70 & 0.80 & 2113 & 591 & 16.6 & 300 \\
Berseem & 2.96 & 0.22 & 1.54 & 120 & 25 & 10.5 & 2.5 \\
CD $(0.05)$ & 0.166 & 0.065 & 0.055 & 8.063 & 5.961 & 0.340 & 7.488 \\
\hline
\end{tabular}

cropping pattern under the Fox nut-water chestnutberseem cropping system exhibited superiority in having the higher concentration of nutrients over the other crops vis-a-vis other crop combinations. The concentrations of $\mathrm{Fe}, \mathrm{Mn}$, and $\mathrm{Cu}$ in plants had definite relationship with their availability status of soils. The results thus, indicate that soil test values corroborate with plant analysis.

\section{Conclusion}

The three years' pooled data showed that the soils, with the Fox nut-water chestnut-berseem cropping system, had higher water holding capacity than the soils with the Fox nut-fox nut and six other Fox nut-based cropping systems. This cropping system could lead to a significant increase in organic carbon, $\mathrm{N}, \mathrm{P}, \mathrm{Fe}$ and $\mathrm{Mn}$ contents of the soil. However, for enhancing the $\mathrm{Cu}$ and Zn concentrations in soil, Fox nut-rice-berseem system appeared to be the most efficient one. The crops included in Fox nut-water chestnut-berseem cropping system exhibited a maximum concentration of nutrients in their tissues. Berseem recorded the highest concentration of $\mathrm{N}$, and K. Fox nut had the highest tissue concentrations of the less soluble Fe and Mn, whereas water chestnut accumulated maximum contents of $\mathrm{P}, \mathrm{Cu}$ and $\mathrm{Zn}$. Based on the findings, we recommend cultivating fox nut in cropping system mode must include at least one leguminous crop for the sustainable use of soil.

\section{References}

Aggrawal, P., Parashar, D.K., Kumar, V. and Gupta, R.P. (1997). Effect of Kharif green manuring and
Rabi tillage on physical properties of puddled clay loam soil under rice-wheat rotation. Journal of the Indian Society of Soil Science 45, 434-38.

Balamurugan, J., Kumaraswamy, K. and Rajarajan, A. (2000). Effect of Eucalyptus citriodora on the physical and chemical properties of soils. Journal of the Indian Society of Soil Science 48, 491-495.

Barko, J. and James, W.F. (1998). Effects of submerged aquatic macrophytes on nutrient dynamics, sedimentation, and resuspension. In 'The Structuring Role of Submerged Macrophytes in Lakes'. (Eds. E. Jeppensen, M. Sondergaard, K. Christoffersen,) pp. 197-214. (Springer Verlag, New York)

Bellaki, M.A. and Badanur, V.P. (1994). Effect of crop residue incorporation on physical and chemical properties of Vertisols and yield of sorghum. Journal of the Indian Society of Soil Science 42, 533-535.

Campbell, P.G.C., Lewis, A.G., Chapman, P.M., Crowder, A.A., Fletcher, W.K., Imber, B., Luoma, S.N., Stokes, P.M. and Winfrey, M. (1988). Biologically available metals in sediments. Publ. No. 27694, National Research Council of Canada, Ottawa, pp. 298.

Carter, M.R., Sanderson, J.B., Ivany, J.A. and White, R.P. (2002). Influence of rotation and tillage on forage maize productivity, weed species, and soil quality of a fine sandy loam in the coolhumid climate of Atlantic Canada. Soil and Tillage Research 67, 85-98. 
Galantini, J.A., Landriscini, M.R., Iglesias, J.O., Miglierina, A.M. and Rosell, R.A. (2000). The effects of crop rotation and fertilization on wheat productivity in the Pampean semiarid region of Argentina. II. Nutrient balance, yield and grain quality. Soil and Tillage Research 53, 137-144.

Gambrell, R.P., DeLaune, R.D. and Patric, Jr. W.H. (1991). Redox processes in soils following oxygen depletion. In 'Plant life under Oxygen Deprivation: Ecology, Physiology and Biochemistry'. (Eds. M.B. Jackson, D.D. Davies, H. Lambers) pp. 101-117 (SPB Academic, The Hague,).

Ganeshamurthi, A.N. (2009). Soil changes following long-term cultivation of pulses. The Journal of Agricultural Science 147, 699-706.

Guilizzoni, P. (1991). The role of heavy metals and toxic materials in the physiological ecology of submerged macrophytes. Aquatic Botany 41, 87109.

Jackson, M.L. (1973). Soil Chemical Analysis. pp. 498. (Prentice Hall of India Pvt. Ltd., New Delhi).

Jha, B.K., Kumar, L., Gupta, V.K., Singh, I.S. and Jee, J. (2012). An overview of Fox nut cultivation. In 'Status of Agricultural Development in Eastern India' (Eds. Bhatt et al.) pp. 361-369. (ICARRCER, Patna, Bihar).

Jha, P. and Rattan, R.K. (2007). Mineralization of carbon and $\mathrm{P}$ in soil as affected by soil moisture regimes and incorporation of crop residues. Journal of the Indian Society of Soil Science 55, 218-221.

Jha, S.N. and Dutta, R.N. (2003). Soil-waterchemistry of Fox nut (Euryale ferox Salisb.) cultivation. In 'Fox Nut' (Eds. Mishra, R. K., Jha, V. and Dehadrai, P.V.). pp 73-84. (DIPA, ICAR, New Delhi).

Jones, R. (1972). Comparative studies of plant growth and distribution in relation to water logging: The uptake of iron and manganese by dune and dune slack plants. Journal of Ecology 60, 131-139.

Kumar, L., Gupta, V.K., Jha, B.K., Singh, I.S., Bhatt, B.P. and Singh, A.K. (2013). Fox nut ki kheti ki unnat takneek. Technical BulletinNo. E-116/Patna-73. ICAR RCER, Patna.
Kumar, L., Gupta, V.K., Khan, M.A., Singh, S.S., Jee, J. and Kumar, A. (2011). Field based Fox nut cultivation for improving cropping intensity of rice fields. Bihar Journal of Horticulture 1, 7172.

Kumar, L., Choudhary, A.K., Bhatt, B.P. and Singh, K.P. (2015). Genetic divergence in makhana (Euryale ferox Salisb.). Indian Journal of Horticulture 72, 365-369.

Kumar, B. and Prasad, R.K. (2008). Integrated effect of mineral fertilizers and green manure on crop yield and nutrient availability under rice-wheat cropping system in calciorthents. Journal of Indian Society of Soil Science 56, 209-214.

Lan, C., Chen, G., Li, L. and Wang, M.H. (1992). Use of Cattails in treating wastewater from $\mathrm{Pb} / \mathrm{Zn}$ mine. Environmental Management 16, 75-80.

Lindsay, W.L. and Norvell, W.A. (1978). Development of DTPA soil tests for zinc, iron, manganese, and copper. Soil Science Society of America Journal 42, 421-428.

Mandal, R.N., Saha, G.S. and Sarangi, N. (2010). Harvest and processing of Fox nut (Euryale ferox Salisb.)-An unique assemblage of traditional knowledge. Indian Journal of Traditional Knowledge 9, 684-688.

Patrick, W.H. and Mikkelsen, D.S. (1971). Plant nutrient behavior in flooded soil. In 'Fertilizer Technology and Use, $2^{\text {nd }}$ Edition'. (Eds. R.A. Olson,). pp. 187-215. Soil Science Society. (Amer. Inc., Madison, Wisc. U.S.A).

Pannu, R.P.S., Singh, Y., Singh, B. and Khind, C.S. (2001). Long-term effects of organic materials on depth-wise distribution of different $\mathrm{K}$ fractions in soil profile under rice-wheat cropping systems. Journal of Potassium Research 17, 34-38.

Ponnamperuma, F.N. (1972). The chemistry of submerged soils. Advances in Agronomy 24, 1996.

Portielje, R. and Roijackers, R.M.M. (1995). Primary succession of aquatic macrophytes in experimental ditches in relation to nutrient input. Aquatic Botany 50, 127-140. 
Rattan, R.K., Patel, K.P., Manjaiah, K.M. and Datta, S.P. (2009). Micronutrients in soil, plant, animal and human health. Journal of the Indian Society of Soil Science 57, 546-558.

Rattray, M.R., Howard-Williams, C. and Brown, J.M.A. (1991). Sediment and water as sources of $\mathrm{N}$ and $\mathrm{P}$ for submerged rooted aquatic macrophytes. Aquatic Botany 40, 225-237.

Sekhar Chandra, Ch., Balaguravaiah, D. and Naidu, M.V.S. (2014). Studies on genesis, characterization and classification of soils in Central and Eastern Parts of Prakasam district in Andhra Pradesh. Agropedology 24, 125-137.

Singh, I.S., Kumar, L., Singh, A.K., Bhatt, B.P. and Singh S.P. (2014). Impact of makhana (Euryale ferox Salisb.) based cropping systems on nutrient dynamics of Inceptisols of north Bihar. International Journal of Agricultural and Statistical Sciences 10, 125-129.

Varvel, G.E. (2000). Crop rotation and N effects on normalized grain yields in a long term study. Agronomy Journal 92, 938-941.

Verma, V.K., Setia, R.K., Sharma, P.K., Singh, C. and Kumar, A. (2005). Micronutrient distribution in soils developed on different physiographic units of Fatehgarh Sahib district of Punjab. Agropedology 15, 70-75.

Zhang, F., Romheld, V. and Marschner, H. (1989). Effect of zinc deficiency in wheat on the release of zinc and iron mobilizing root exudates. Journal of Plant Nutrition and Soil Science 152, 205-210.

Received: April, 2018

Accepted: January, 2019 